\title{
THE WHITEFLY SPECIES (HEMIPTERA, ALEYRODIDAE) WITH DARK PUPARIUM AND PUPAL CASE RECORDED IN CROATIA
}

\author{
Mladen Šimala ${ }^{1}$, Tatjana Masten Milek ${ }^{2}$ \& Maja Pintar ${ }^{1}$ \\ ${ }^{1}$ Croatian Centre for Agriculture, Food and Rural Affairs, Institute for Plant Protection \\ Rim 98, 10000 Zagreb, Croatia (mladen.simala@hcphs.hr) \\ ${ }^{2}$ Croatian Centre for Agriculture, Food and Rural Affairs, Svetošimunska 25, 10000 Zagreb, Croatia
}

Šimala, M., Masten Milek, T. \& Pintar, M.: The whitefly species (Hemiptera, Aleyrodidae) with dark puparium and pupal case recorded in Croatia. Nat. Croat., Vol. 24, No. 1, 111-125, 2015, Zagreb.

A check list of whiteflies in Croatia contains 31 species. This is the result of browsing the literature of faunistic investigations of whiteflies in Croatia from 1940 to 2007 and faunistic research done by the authors in the period 2005-2007. During faunistic investigations, 7 of the total 31 recorded species were whitefly species with dark puparia and pupal cases. These are the following species: Aleuroclava hikosanensis Takahashi 1938, Aleurolobus olivinus Silvestri 1911, Aleurolobus wunni Ryberg 1938, Aleurotuba jelinekii Frauenfeld 1867, Aleuroviggianus adrianae Iaccarino 1982, Simplaleurodes hemisphaerica Goux 1945 and Tetralicia ericae Harrison 1917. In addition to these, another 2 whitefly species with dark puparia and pupal cases were recorded later in Croatia. These are Aleurocanthus spiniferus (Quaintance 1903), which was reported for the first time in Croatia in 2012 and Aleuroclava aucubae (Kuwana 1911), first detected in Croatia in 2013.

Key words: whiteflies, Aleyrodidae, dark puparium, dark pupal case, Croatia

Šimala, M., Masten Milek, T. \& Pintar, M.: Vrste štitastih moljaca (Hemiptera, Aleyrodidae) s tamnim puparijem i egzuvijem zabilježene u Hrvatskoj. Vol. 24, No. 1, 111-125, 2015, Zagreb.

Popis vrsta štitastih moljaca Hrvatske sadrži 31 vrstu. Rezultat je to pregleda literature o faunističkom istraživanju štitastih moljaca u Hrvatskoj od 1940. do 2007. i faunističkih istraživanja koja su obavili autori u razdoblju 2005.-2007. Tijekom faunističkih istraživanja, 7 od ukupno 31 zabilježene vrste bile su vrste štitastih moljaca s tamnim puparijem i egzuvijem. To su sljedeće vrste: Aleuroclava hikosanensis Takahashi 1938, Aleurolobus olivinus Silvestri 1911, Aleurolobus wunni Ryberg 1938, Aleurotuba jelinekii Frauenfeld 1867, Aleuroviggianus adrianae Iaccarino 1982, Simplaleurodes hemisphaerica Goux 1945 i Tetralicia ericae Harrison 1917. Pored navedenih, još su 2 vrste štitastih moljaca s tamnim puparijem i egzuvijem zabilježene kasnije. To su Aleurocanthus spiniferus (Quaintance 1903) koja je nađena prvi puta u Hrvatskoj 2012. i Aleuroclava aucubae (Kuwana 1911), prvi puta detektirana u Hrvatskoj 2013. godine.

Ključne riječi: štitasti moljci, Aleyrodidae, tamni puparij, tamni egzuvij, Hrvatska

\section{INTRODUCTION}

The last updated check list of the world's whiteflies comprises 1556 species from 161 genera (MARTin \& Mound, 2007). According to MARTin et al. (2000) the whitefly fauna of Europe and the Mediterranean Basin comprises 56 species that are considered to be native or naturalized, accommodated within 25 genera. The check list of whiteflies in Croatia contains 31 species belonging to 18 genera (Šimala \& Masten MileK, 2008). The list also includes the species Aleuroclava hikosanensis Takahashi 1938, Aleurolobus olivinus 
Silvestri 1911, Aleurolobus wunni Ryberg 1938, Aleurotuba jelinekii Frauenfeld, 1867, Aleuroviggianus adrianae Iaccarino 1982, Simplaleurodes hemisphaerica Goux 1945 and Tetralicia ericae Harrison 1917, which have originally dark puparim and pupal cases. All these species are, according to Martin et al. (2000), distributed in Europe and the Mediterranean Basin, except for A. hikosanensis, which is a non-European whitefly species (TAKAHASHI, 1938). The alien species Aleurocanthus spiniferus (Quaintance 1903) and Aleuroclava aucubae (Kuwana 1911), which have also dark pupariam were recorded for the first time in Croatia later, in 2012 (Šimala \& Masten MileK, 2013; Šimala \& Masten MileK, 2013a; Šmala et al., 2013) and 2013 respectively (Šimala et al., 2013; Šimala et al., 2014).

The emergence of the adult whitefly insect from a totally dissimilar larval exoskeleton has led to the term "puparium" being applied to the fourth instar larva and the exuvium is referred to as a "pupal case". Aleyrodid pupal cases provide many characteristics which are used to assist in the identification of species. They are very small, those of most species being between $0,5 \mathrm{~mm}$ and 1,75 $\mathrm{mm}$ long. The best mounts are usually obtained from pupal cases from which adults have recently emerged. With adequate maceration and subsequent rinsing, puparia from which adults have not yet emerged can make excellent mounts (MARTIN, 1987). The taxonomy of Aleyrodidae is mainly based on the empty pupal cases and, more than in other insect groups, on the morphology of the derm. The empty pupal cases, which are attached to the leaves and occasionally to the branches of plants, can be collected almost throughout the entire year. The colour of the pupal case is usually typical for the species and genus. The colour pattern can be typical for a species, but in other species colour patterns may be influenced by exposurn and season. Occasionally, a colour pattern is characteristic of a species population (Bink-Moenen, 1983). Dark whitefly pupal cases and puparia in the preparation procedure for microscopic examination should be bleached.

\section{MATERIALS AND METHODS}

Faunistic investigations of whitefly species with dark puparim and pupal cases were conducted on the entire territory of Croatia in the period 2005-2007 and in certain coastal and continental counties only in 2012 and 2013. Whiteflies were collected by visual survey of host plant leaves, with the help of a magnifying lens of 10 times magnification, for the presence of their dark puparia or pupal cases. Host plants were identified according to Domac (1967; 1994) and ŚILIĆ (1988; 1988a; 1988b; 1990).

The leaf samples with preimaginal whitefly stages were placed and stored dry in envelopes until whitefly preparation (MARTIN, 1987; 1999). Puparia and pupal cases were picked from the leaves with an entomological needle, bleached in a freshly prepared mixture of hydrogen peroxide and ammonia solution and finally slide-mounted in Canada balsam as permanent microscopic slides according to the modified WATSON \& CHANDLER (1999) method. Bleaching should be monitored as it can be very rapid and may be stopped quickly when the cuticle becomes brown and translucent by adding of a few drops of a water-soluble acid.

All whiteflies collected from the leaf samples were identified to the species level on the basis of the morphological characteristics of puparium and/or pupal case, using the classical identification method according to relevant morphological keys. Keys according to Bink-Moenen (1992), Dubey \& Ko (2012), Hodges \& Evans (2005), Martin (1987), Martin et al. (2000), SuH (2010) and TAKAHASHI (1938; 1952) were used for the identification. The nomenclature used follows MARTin \& Mound (2007). For an accurate identifi- 
cation, a stereomicroscope (Nikon SMZ 800) and a compound microscope (Olympus BX 50 and BX 51) were used. Photographs were taken under a compound microscope Olympus BX 51 equipped with a DP 25 Digital Camera. Verification of all identifications of whitefly species recorded by faunistic investigations was done by M. G. M. Jansen (Plant Protection Service, Wageningen, The Netherlands) and G. Seljak (Kmetijsko gozdarski zavod Nova Gorica, Slovenia). Slide-mounted specimens were deposited in the collection of the laboratory for zoology of the Institute for Plant Protection - Croatian Centre for Agriculture, Food and Rural Affairs and at the Croatian Natural History Museum in Zagreb.

The localities of findings were mapped according to the Universal Transverse Mercator coordinate system (HoRvat et al., 2003). For each sampling site, the UTM-grid code was given.

\section{RESULTS AND DISCUSSION}

During the faunistic research, a total of nine whitefly species with dark puparia and pupal cases were recorded in Croatia: A. hikosanensis, A. olivinus, A. wunni, A. jelinekii, A. adrianae, S. hemisphaerica, T. ericae, A. spiniferus and A. aucubae.

\section{Aleuroclava hikosanensis Takahashi 1938}

A. hikosanensis is an Eastern Palearctic species distributed in Japan and Korea (Evans, 2006). It was described by TAKAHASHI (1938) as Aleurotuberculatus hikosanensis. JesudasAN \& DAvid (1990) redefined Aleuroclava and Aleurotuberculatus as distinct genera and the 66 species of whiteflies known under the Aleuroclava / Aleurotuberculatus group (Mound \& Halsey, 1978) were divided into eight distinct genera. According to this study Aleuroclava hikosanensis belongs to the genus Aleurotuberculatus. The genus Aleurotuberculatus was synonymised with Aleuroclava by MARTin (1999). According to the recent check list of the world's whiteflies (Martin \& Mound, 2007) the genus Aleuroclava Singh is composed of 122 species, mainly Oriental or Australasian, but with some species also present in the Palearctic Region. A. hikosanensis feeds on plants belonging to eight families: Aquifoliaceae, Buxaceae, Ericaceae, Lauraceae, Myricaceae, Pittosporaceae, Styracaceae and Theaceae (Evans, 2006). Worldwide, the trade in plants has increased enormously during the last decade. Because of the increased import of different ornamentals, the possibility of introduction of new whitefly species has also increased. The species $A$. hikosanensis was detected in Croatia only in garden centres, on macro bonsai plants of Ilex crenata Thunb. imported from Japan. It is not known if it could become naturalised in Croatia (Šimala et al., 2009).

Collection data: Lučko (WL 6867) 27 April 2005, Turanj (WJ 3368) 9 June 2006 on I. crenata (Fig.1).

The pupal case of the species A. hikosanensis is black, strongly sclerotized, with a little wax along the whole margin, 0,9 mm long and 0,69 $\mathrm{mm}$ wide (Fig.2). It is the broadest at the basal abdominal segment, distinctly constricted on the posterior half of abdomen, less so across the thoracic tracheal clefts, broadly rounded on the anterior and posterior margins. Mid-thoracic suture reaching the margin of dorsal disk; thoracic segments faintly discernible; head with a pair of oblique slender paler areas on the dorsum; transverse suture between the thorax and abdomen not reaching the margin of dorsal disk; abdominal segments discernible on the median area. Submarginal area is narrow, distinctly differentiated, with markings. Dorsal disk lacking distinct tubercles, but with 


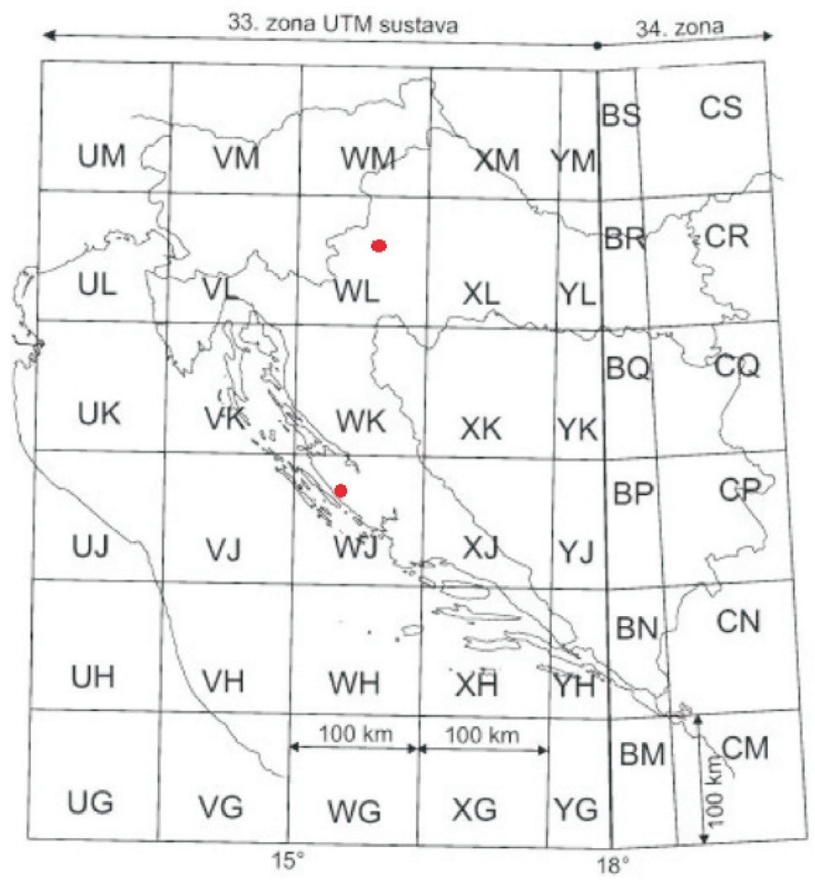

Fig. 1. Finding places of Aleuroclava hikosanensis Takahashi 1938 in Croatia

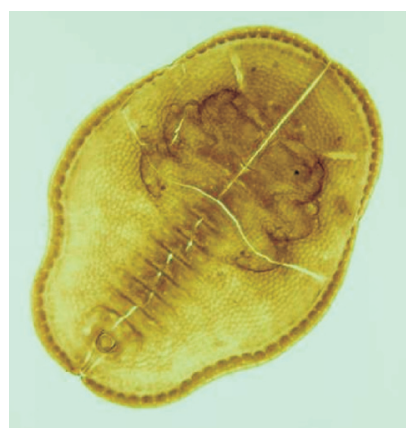

Fig. 2. Permanent microscopic slide of a pupal case of Aleuroclava hikosanensis Takahashi 1938 (Photo: M. Šimala)

some minute circular pores scattered, very densely with numerous rather large black granules except on the marginal narrow area and on the median area of each abdominal segment; longitudinal wavy furrow-like sculptures present on the median area of each abdominal segment. Marginal teeth small, rounded on the free margin, much wider than longer, irregular in shape and size. Posterior pair of usual marginal setae short, thin; a pair of longer fine setae present near the hind end of dorsum. Thoracic tracheal folds broadened basally, without sculptures; the clefts small, but distinct, sclerotized on the margin, widely opening, wider than long, without teeth. Caudal furrow distinct, short, somewhat longer than the vasiform orifice including the anterior marginal area, without sculptures; the cleft as in the thoracic ones, but larger. Vasiform orifice small, between 2 longitudinal thickenings, much thicker on the margin, distinctly notched at the hind end, almost equal in length and width, without marginal teeth; the anterior marginal area much more expanded, not distinctly defined from the $8^{\text {th }}$ abdominal segment. Operculum occupies most of the orifice. Venter with rather large faint circular markings, with no marginal rim. Antennae much reduced in size (TAKAHASHI, 1938).

\section{Aleurolobus olivinus Silvestri 1911}

Aleurolobus Quaintance \& Baker is a moderately large genus that currently includes 84 species (Martin \& Mound, 2007) with the majority of the species from the Oriental Region (Dubey \& Ko, 2009). Representatives of the genus Aleurolobus often occur at low population densities, with puparia sparsely scattered on their hosts. Even at higher densities, colonies do not usually occur in the dense aggregations characteristic of some other genera (MARTin, 1999). A. olivinus is only known from the Mediterranean countri- 
es, where it occasionally becomes a minor pest of olives. Although clearly favouring oleaceous hosts, it has also been recorded on Erica (MARTIN et al., 2000). NovaK (1940) cited a finding of high population of this species on upper side of olive leaves in Split and in the surrounding coastal areas. It was recorded also on Phillyrea angustifolia L. and Ph. latifolia L. in the southern part of the coast at the peninsula Prevlaka, in period 2005-2006 by ŽANIĆ (2006).

Collection data: Pločice (BN 8707) 17 May 2007, Vitaljina (BN 9202) 17 May 2007 on Ph. angustifolia (Fig.3).

Puparia and pupal cases of A. olivinus can be found on both sides of leaves. Cuticle is black with short, translucent fringe of wax-hairs. Pupal case is broadly suboval to subcircular, 1,2 mm - 1,75 mm long and $0.9 \mathrm{~mm}-1,55 \mathrm{~mm}$ wide (Fig.4). Margin is crenate, marginal setae are present, tracheal pore areas are differentiated from margin as a comb of several small teeth. Submargin is separated from dorsal disc by a furrow, interrupted at caudal area. Median moulting suture is variating in length, reaching to or beyond submarginal furrow occasionally up to body-margin; transverse one reaching submarginal furrow. Abdominal segments I-VI are subequal in length medially, segment VII is slightly shorter than VI medially. Cephalic, $1^{\text {st }}$ and $8^{\text {th }}$ abdominal setae are short, caudal setae are absent. Row of 12 pairs of short, submarginal setae is close to submarginal furrow, two pairs of minute setae on cephalous are close to body-margin (BINKMoenen \& Gerling, 1990). Vasiform orifice is rounded-triangular, fully occupied by similarly-shaped operculum, which covers lingula, but with lingula remaining clearly visible through operculum (MARTin et al., 2000).

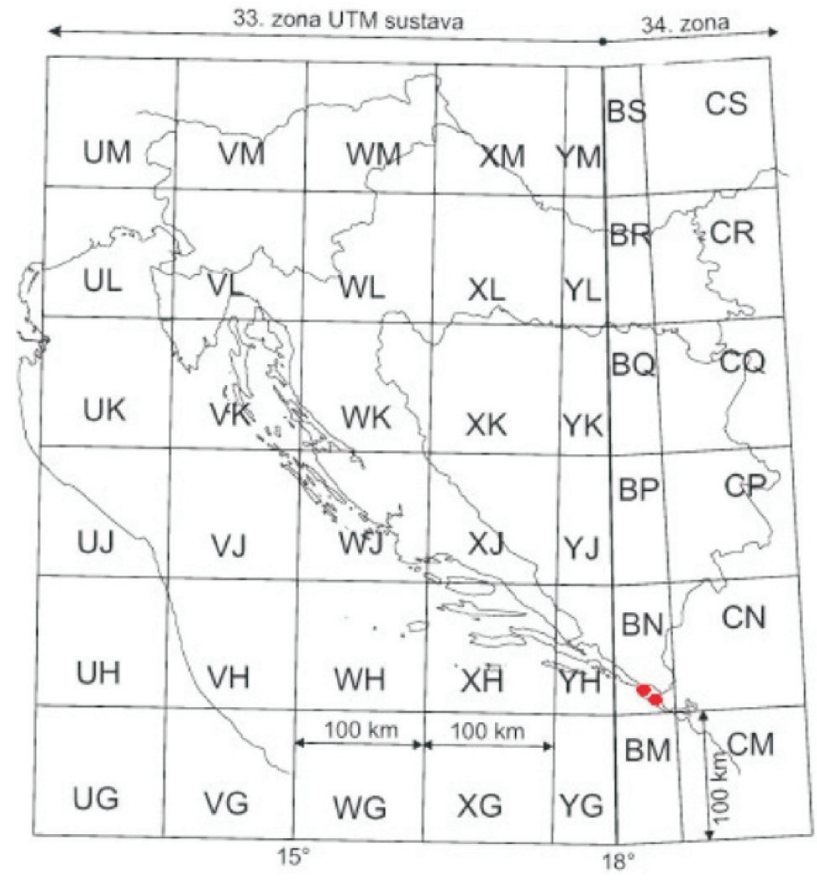

Fig. 3. Distribution of Aleurolobus olivinus Silvestri 1911 in Croatia determined by the authors

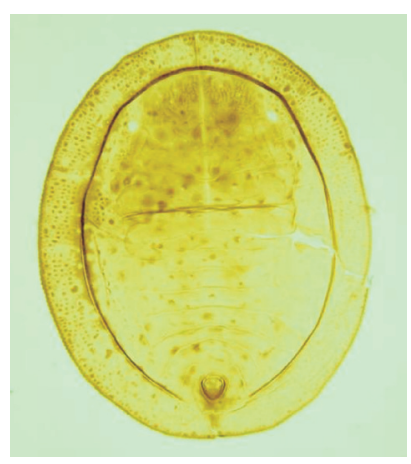

Fig. 4. Permanent microscopic slide of a pupal case of Aleurolobus olivinus Silvestri 1911 (Photo: M. Šimala) 


\section{Aleurolobus wunni Ryberg 1938}

A. wunni is a European whitefly species which appears to be at least moderately polyphagous (Martin et al., 2000). Mound \& Halsey (1978) listed the following hosts: Aristolochiaceae: Asarum europaeum L.; Caprifoliaceae: Lonicera fragrantissima Lindl. et Paxt., Symphoricarpos albus (L.) Blake; Labiatae: Phlomis sp.; Ranunculaceae: Cimcifuga sp., Clematis vitalba L.; Rosaceae: Spiraea sp. Zahradnik $(1985,1991)$ added Rhamnus frangula L. (Rhamnaceae), Linnaea borealis L., Lonicera nigra L., L. tatarica L. and L. xylosteum L. (Caprifoliaceae) to the host list of $A$. wunni. In northern European countries $A$. wunni mainly lives on L. borealis, whereas in Central Europe its main host seems to be A. europaeum (JANSEN, 2001). The only observed host in Croatia was A. europaeum, which is distributed in continental forests. The species is present and generally found in small numbers in most Central and East-European countries from Sweden to Italy and from France to Russia, but seems absent from most West European countries like the Netherlands and Great Britain. The puparium hibernates and the adults appear in May. Puparia of the new generation are present from September onwards (JANSEN, 2001).

Collection data: Carevdar (XM 2703) 8 May 2005, Haganj (XL 2285) 13 August 2006, Plitvička jezera (WK 4970) 13 October 2006, Rudanovac (WK 5458) 13 October 2006, Daruvar (XL 7352) 28 October 2006, Slani Dol (WL 4971) 7 July 2007, Budinjak (WL 3870) 8 August 2007 on A. europaeum (Fig.5).

The puparium of $A$. wunni is black, rarely white (Dobreanu \& Manolache, 1969) and immediately recognizable from the characteristic white wax filaments (Huldén, 1986). The black cuticle and the wide submargin separated from the dorsal disc by a suturelike fold are typical for the genus Aleurolobus. Within the genus, A. wunni can be distin-

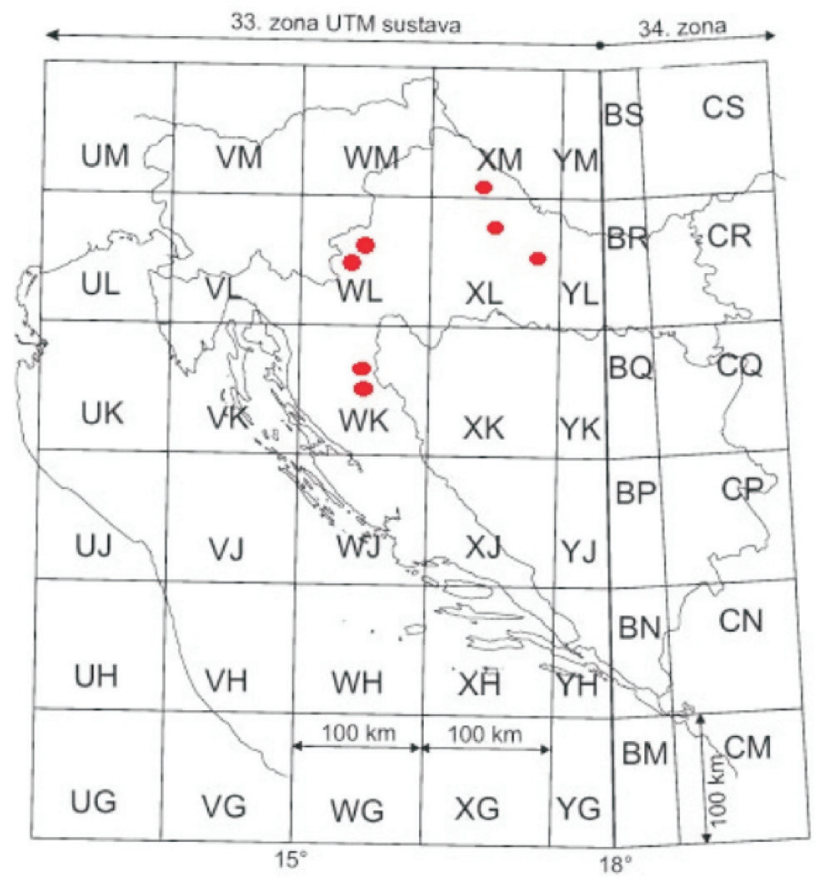

Fig. 5. Distribution of Aleurolobus wunni Ryberg 1938 in Croatia determined by the authors

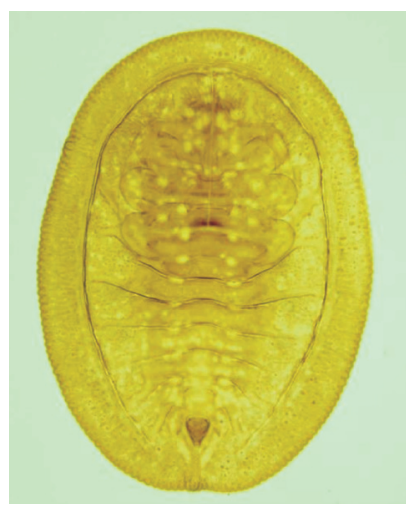

Fig. 6. Permanent microscopic slide of a puparium of Aleurolobus wunni Ryberg 1938 (Photo: M. Šimala) 
guished from other European species by its ovoid outline, the absence of eyespots, the vasiform orifice, which is generally equal in length and width at its anterior end, and by the thoracic tracheal teeth being slightly protuberant marginally (JANSEN, 2001) (Fig.6). Caudal tracheal opening is not differentiated (MARTin et al., 2000). The puparium is 1,15 $\mathrm{mm}-1,20 \mathrm{~mm}$ long and, $0.85 \mathrm{~mm}-0.90 \mathrm{~mm}$ wide (Dobreanu \& Manolache, 1969).

\section{Aleurotuba jelinekii Frauenfeld 1867}

A. jelinekii is one of the most common whitefly species across Europe, including northern localities such as the British Isles (Mound, 1966). It is widespread in the southern half of Europe and in many Mediterranean countries where it may be a pest in public greenery (JANSEN, 2001). This whitefly is widely spread across the coastal part of Croatia (ŠimalA, 2008). It is most frequently encountered on the widely-planted Viburnum tinus L. (Caprifoliaceae), but Arbutus unedo L. (Ericaceae) is also favoured (Martin et al., 2000). According to Mound \& Halsey (1978), other hosts recorded are V. rotundifolia Michx. and Myrtus communis L. (Myrtaceae). The species is univoltine (IAcCARINo \& Viggiani, 1984; Jansen, 2001)

Collection data: Trsteno (YH 4433) 1 July 2005, Grožnjan (UL 9925) 7 July 2005, Živogošće (XH 7584) 16 September 2005, Cavtat (BN 7118) 17 September 2005, Poreč (UL 9009) 17 May 2006, Povlja (XH 4999) 26 May 2006, Pakoštane (WJ 4062) 8 June 2006, Sveti Petar (WJ 3072) 20 June 2006, Soline (BN 7221) 28 September 2006, Saplunara (YH 2430) 28 September 2006, Čilipi (BN 7516) 14 December 2006 on A. unedo; Soline (BN 7221) 28 September 2006 on M. communis; Biograd (WJ 3665) 9 June 2005, Murter (WJ 4851) 7 June 2005, Kaštel Sućurac (XJ 1522) 8 June 2005, Trilj (XJ 3930) 24 June 2005, Pakoštane (WJ 4062) 15 June 2006, Dubrovnik (BN 6126) 1 July 2005, Seget Donji (WJ 9919) 26 July 2005, Novigrad Istarski (UL 8719) 16 June 2005, Metković (YH 1670) 30 June 2005,

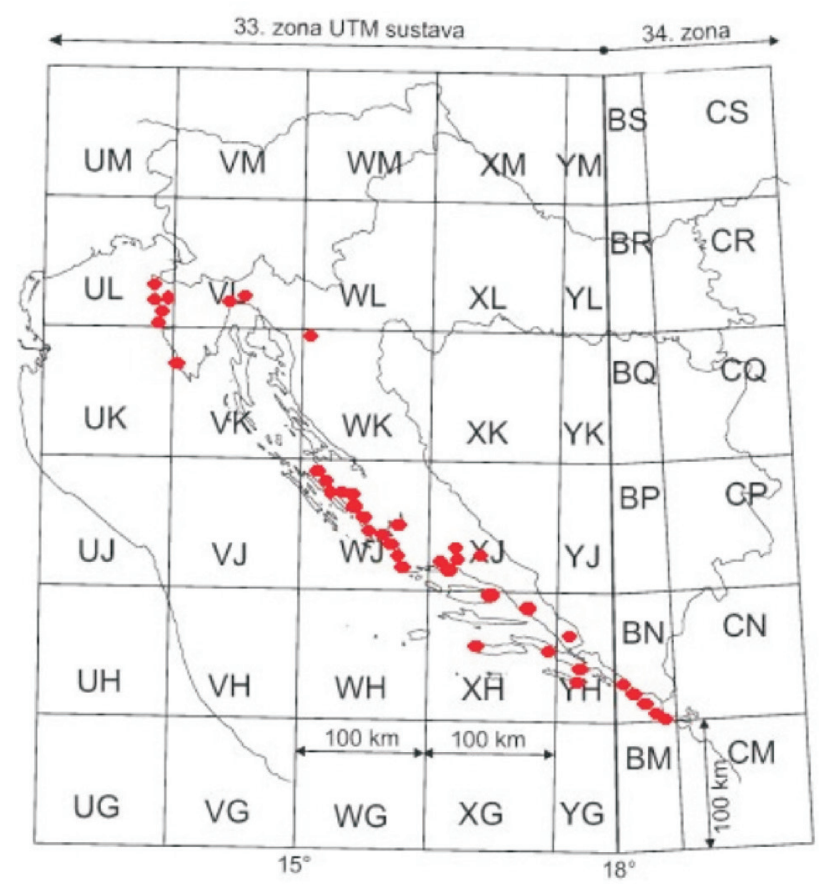

Fig. 7. Distribution of Aleurotuba jelinekii Frauenfeld 1867 in Croatia determined by the authors

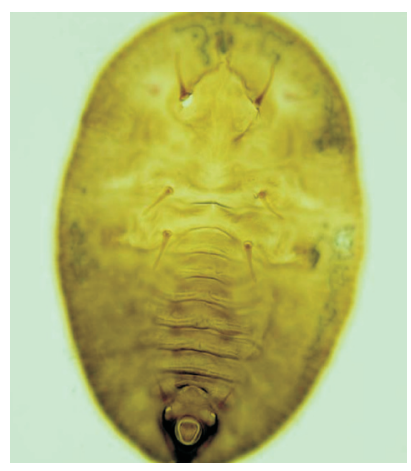

Fig. 8. Permanent microscopic slide of a pupal case of Aleurotuba jelinekii Frauenfeld 1867 (Photo: M. Šimala) 
Umag (UL 8432) 2 August 2005, Opatija (VL 4520) 25 August 2005, Veli Brijun (VK 0175 26 August 2005, Poreč (UL 9009) 1 September 2005, Skradinski Buk (WJ 7851) 15 September 2005, Primošten (WJ 7526) 15 September 2005, Vela Luka (XH 4058) 20 September 2005, Matulji (VL 4723) 29 September 2005, Solin (XJ 2021) 5 October 2005, Split (XJ 1919) 6 October 2005, Vrsar (UL 9000) 17 May 2006, Nin (WJ 1499) 30 May 2006, Tribunj (WJ 6045) 30 May 2006, Petrčane (WJ 1392) 30 May 2006, Šibenik (WJ 7343) 31 May 2006, Klis (XJ 2324) 31 May 2006, Zadar (WJ 1884) 31 May 2006, Vrana (WJ 4566) 8 June 2006, Žuljana (YH 0051) 22 June 2006, Rogoznica (WJ 7819) 4 July 2006, Molunat (BN 8903) 24 July 2006, Jadrija (WJ 6841) 13 August 2006, Kapela (WK 5362) 28 August 2006, Debeljak (WJ 2977) 12 October 2006 on V. tinus (Fig. 7).

A. jelinekii pupal case is black, with dorsal rolls of flocculent white wax, and white waxy marginal fringe. The length of pupal case is $1,1 \mathrm{~mm}$ and the breadth is, $0.8 \mathrm{~mm}$. It is oval, barely constricted at thoracic tracheal pores, dorsum is elevated in mid-line. The margin is regularly toothed. Characteristic are four pairs of blunt siphons or trumpet-like wax-secreting dorsal setae, one pair on eighth abdominal segment and three pairs that are restricted to each of the three thoracic segments (Fig. 8). The dorsal disc is without elongate spines, siphon-like setae or subdorsal compound pores. Vasiform orifice is elongated rectangular, filled by operculum, which conceals lingula (Mound, 1966; JANSEN, 2001).

\section{Aleuroviggianus adrianae Iaccarino 1982}

Aleuroviggianus Iaccarino 1982 is a pan-Mediterranean genus with six species, all occurring on evergreen oaks (Martin et al., 2000; Martin \& Mound, 2007). According to Martin et al. (2000) the type species, A. adrianae is the most common and most widely distributed species, and is recorded in some Mediterranean countries. It lives on Quercus

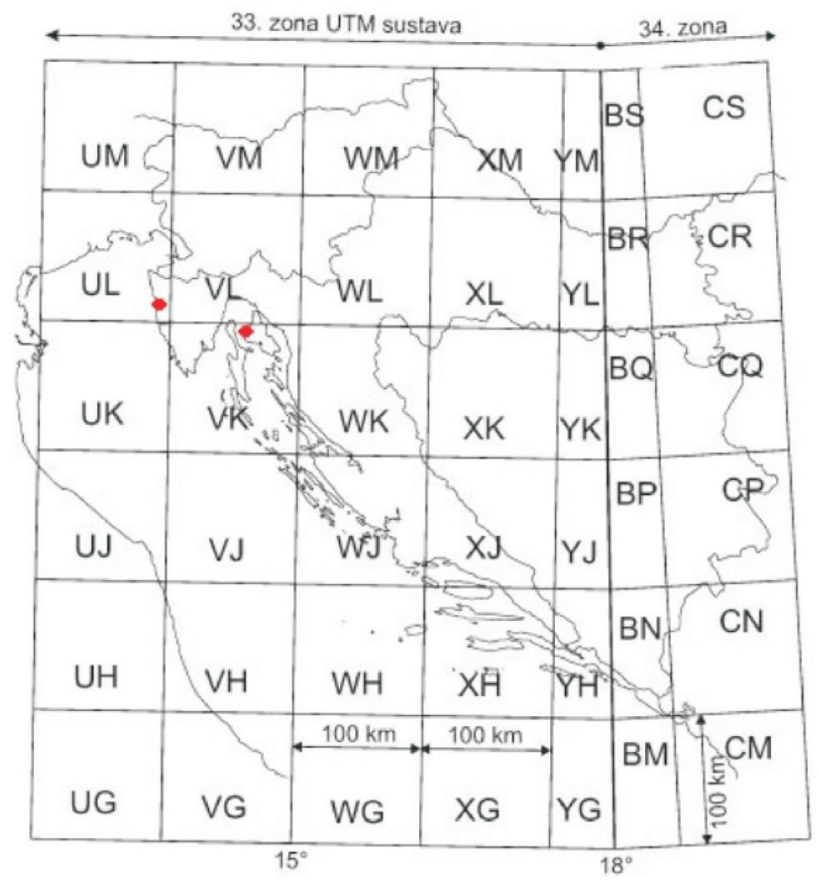

Fig. 9. Distribution of Aleuroviggianus adrianae Iaccarino 1982 in Croatia determined by the authors

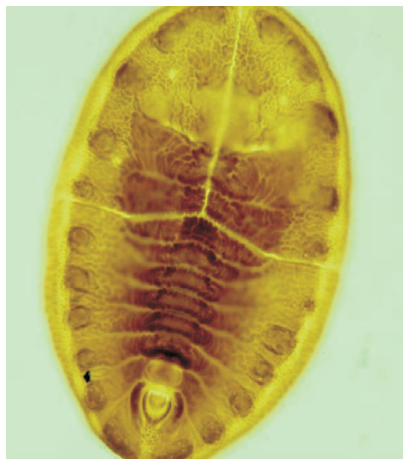

Fig. 10. Permanent microscopic slide of a pupal case of Aleuroviggianus adrianae Iaccarino 1982 (Photo: M. Šimala) 
ilex L., Q. rotundifolia Lam. And Q. suber L. A. adrianae is a univoltine species (BInk-MoENEN, 1992). It was determined by our faunistic research on $Q$. ilex and $Q$. frainetto Ten., only in the northern coastal part of Croatia. $Q$. frainetto has not been registered previously as a host of $A$. adrianae.

Collection data: Poreč (UL 9009) 17 May 2006 on Q. frainetto and Q. ilex; Malinska (VK 6397) 3 May 2006 on Q. ilex (Fig. 9).

The A. adrianae pupal case is distinguishable from other Aleuroviggianus species by its black colour, tuberculate dorsum, elongated shape and the obscured lingula tip (Fig. 10). Subdorsum, except subdorsal tubercle clusters, is less intensely black than the rest of the dorsum. Puparia size is variable even within the same populations, with the length between $0.6 \mathrm{~mm}-0.9 \mathrm{~mm}$ and breadth $0.36 \mathrm{~mm}-0.54 \mathrm{~mm}$. Young fourth instar has tubercle clusters at some distance from apparent margin and deflexed submargin which is much smaller than in the pupal case. Pupal case has seldom visible subdorsal setae situated distal to tubercle clusters or on apparent margin, 6 on abdomen and 6 on cephalothorax. Lingula tip is not always entirely concealed by operculum. Several bulges are present on venter in addition to adhesive sac (BInK-Moenen, 1992). Caudal furrow is broad and punctuated by subcircular rounded-reticulate markings (MARTIN et al., 2000).

\section{Simplaleurodes hemisphaerica Goux 1945}

The genus Simplaleurodes Goux 1945 includes just one species, S. hemisphaerica (MARTIN \& Mound, 2007). This whitefly species is only known from the Mediterranean Basin (Martin et al., 2000). According to Mound \& Halsey (1978), its hosts are two plant species from the family Oleaceae, Phillyrea angustifolia and Ph. Latifolia.

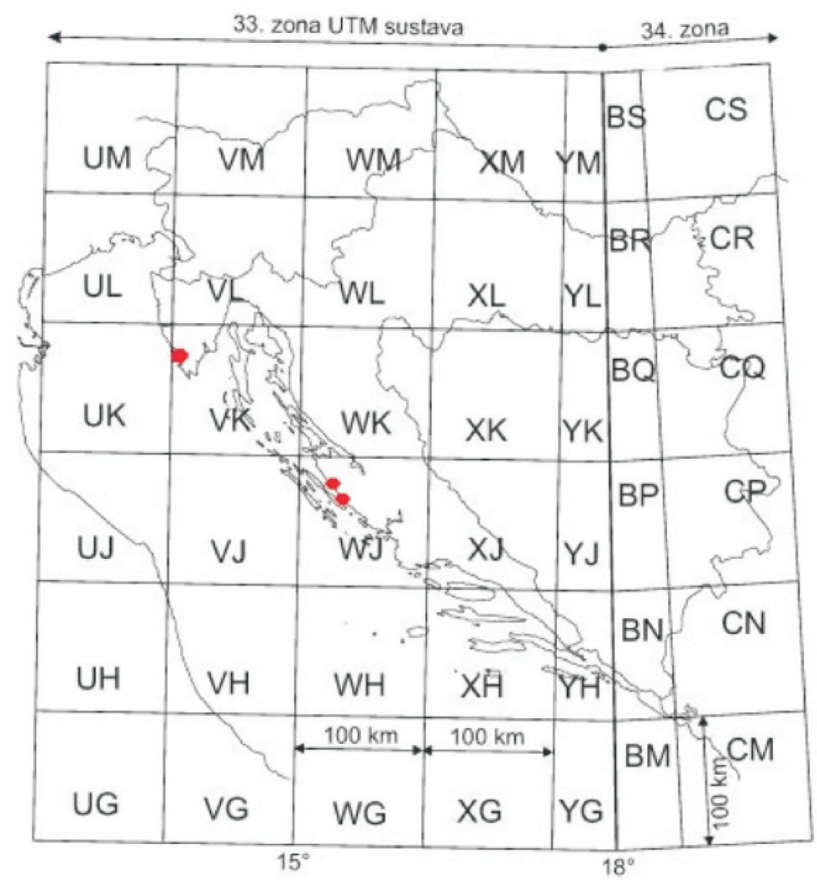

Fig. 11. Distribution of Simplaleurodes hemisphaerica Goux 1945 in Croatia determined by the authors

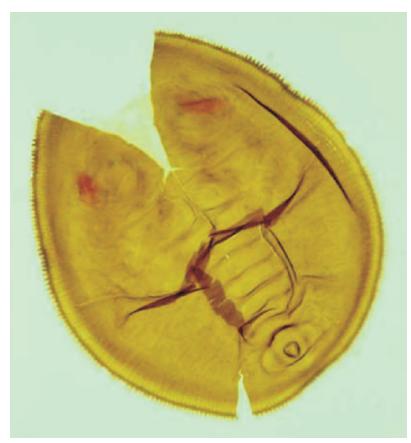

Fig. 12. Permanent microscopic slide of a pupal case of Simplaleurodes hemisphaerica Goux 1945 (Photo: M. Šimala) 
Collection data: Sukošan (WJ 2576) 12 October 2006 on Ph. angustifolia; Fažana (VK 0575) 2 May 2006, Biograd (WJ 3665) 15 May 2007 on Ph. latifolia (Fig. 11).

Puparium is black, almost circular and extremely convex, often split when placed under a microscope slide coverslip (Fig. 12). The margin has coarse teeth, each of which is longer than wide basally (MARTIN et al., 2000). Submargin is emphasized. Thoracic and caudal tracheal folds are not very obvious, but ending in a comb with 4-8 smaller teeth. $8^{\text {th }}$ abdominal segment setae are very short. Vasiform orifice is circular and lingula is mostly covered by trapezoidal operculum, except the rhomboid tip (IACCARINO, 1981).

\section{Tetralicia ericae Harrison 1917}

The genus Tetralicia Harrison 1917 currently includes, beside T. ericae, 5 species (MARTIN \& Mound, 2007). T. ericae is a Palaearctic, univoltine species (RAPISARDA, 1982) distributed in Europe, Asia and Africa (BInk-Moenen, 1983). This is a very common and widespread European whitefly species, but despite their black coloration, its tiny, elongated puparia are difficult to detect, being located on the underside of very narrow and laterally down-curled leaves (Martin et al., 2000). According to Mound \& Halsey (1978), the host plants of T. ericae are Erica species: Erica spp., E. carnea L. and E. tetralix L. The whitefly T. ericae was recorded on three Erica species in coastal and continental part of Croatia.

Collection data: Polače (XH 9439) 28 October 2006, Soline (BN 7221) 28 October 2006 on E. arborea; Budinjak (WL 3870) 8 August 2007, Žamarija (WL 3563) 8 August 2007 on E. carnea; Žuljana (YH 0051) 22 June 2006, Dubrava (YH 0451) 22 June 2006, Orebić (XH 7860) 22 June 2006, Ston (YH 2046) 22 June 2006, Makarska (XH 6495) 27 October 2006 on E. multiflora (Fig.13).

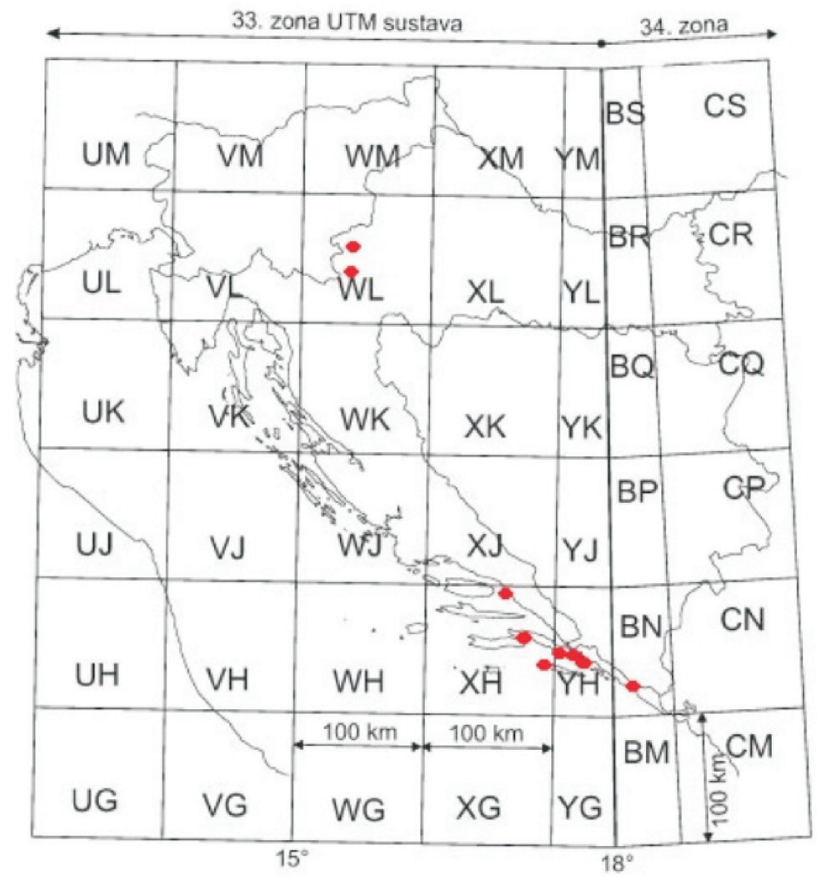

Fig. 13. Distribution of Tetralicia ericae Harrison 1917 in Croatia determined by the authors

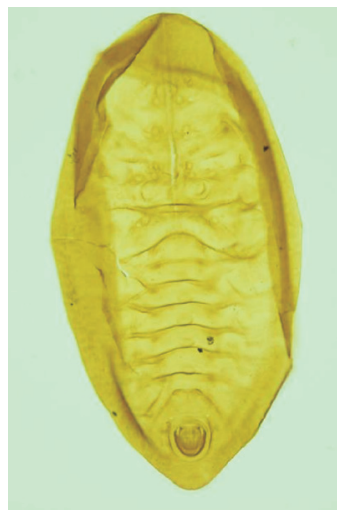

Fig. 14. Permanent microscopic slide of a pupal case of Tetralicia ericae Harrison 1917 (Photo: M. Šimala) 
The pupal case of T. ericae is black, elongated oval to elliptical, $0.95 \mathrm{~mm}-1.05 \mathrm{~mm}$ long and $0.50 \mathrm{~mm}-0.55 \mathrm{~mm}$ wide, orientated along the length of leaf, often concealed by curled leaf margins (Fig. 14). It has a fringe of white wax on the margin. The margin is deflexed ventrally except at caudal extremity, smooth, with well-developed wax pores. Anterior and posterior marginal setae are present. Caudal end is rather protuberant, bearing caudal setae. Dorsal setae are apparently absent from first abdominal segment. Paired setae are present on cephalic region and eighth abdominal segment anterior to orifice. Longitudinal moulting suture reaches true margin. Transverse moulting suture reaches apparent margin. Rhachis has well developed median tubercles on segments two to six. Pores in four paired rows are present on rhachis, subdorsally near rhachis, subdorsally near apparent margin and submarginally on ventral reflexed part of dorsal surface. Vasiform orifice is broadly subcordate with broad margin and ridged internal surface, giving appearance of teeth laterally. Operculum fills orifice, posterior border is rectangular, conceals lingula. Caudal ridges and furrow are not developed (Mound, 1966).

Two introduced whitefly species with dark puparia and pupal cases, A. spiniferus and $A$. aucube were detected for the first time during a regular phytosanitary inspection of the plants in garden centres in Croatia in 2012 and 2013.

\section{Aleurocanthus spiniferus (Quaintance 1903)}

Aleurocanthus Quaintance \& Baker 1914 is a paleotropical genus, currently including 78 species (Martin, 2005; Martin \& Mound, 2007). The species A. spiniferus originated in south-east Asia and has spread widely in tropical and subtropical Asia, and into Africa and the Pacific (Eppo/CABI, 1997). It is listed as a quarantine threat to Europe and is included in the EU Annex II/A1 and in the EPPO A2 list. In Europe, it was reported for the first time in Italy, in 2008 (PorcelLI, 2008). In 2012, the whitefly species A. spiniferus was first found in Croatia, on ornamental potted orange seedlings in one nursery garden in Split (Šimala \& Masten MileK, 2013; Šimala \& Masten MileK, 2013a; Šimala et al., 2013) and in Monte Negro in 2013, on orange and tangerine (RADONJIĆ \& HrNČić, 2013). A. spiniferus is a polyphagous insect. Citrus spp. are the main hosts of economic importance, but according to MARTIN (1996), the pest has been recorded on woody hosts of more than 15 plant families, e.g. grapevine (Vitis vinifera L.), pear (Pyrus spp.), guava (Psidium guajava L.), persimmon (Dyospyros kaki Thunb.) and rose (Rosa spp.) (Oepr/Eppo, 2002). Depending on conditions, the life cycle of $A$. spiniferus generally takes $2-4$ months but there can be three to six overlapping generations a year (EpPo/CABI, 1997).

Collection data: Split (XJ 1919) 30 May 2012 on Citrus $x$ aurantium L.; Split (XJ 1919) 16 July 2013 on Citrus x limon (L.) Burm.f. (Fig. 15).

The puparium of $A$. spiniferus is ovate, shiny-black, in females about $1.25 \mathrm{~mm}$ in diameter and in males up to $1 \mathrm{~mm}$ in diameter. It has 30 pairs of long, acute glandular spines with pointed apex on dorsal surface and a white fringe of waxy secretion along the margin (ЕрPo/CABI, 1997). Margin is toothed with seven to nine marginal teeth in 0.1 $\mathrm{mm}$, submargin with 11 pairs of singly placed spines, five pairs of which are situated on cephalothorax (Fig. 16). Submarginal spines are not placed in transverse rows, but bases of posterior-most $2^{\text {nd }}$ and/or $3^{\text {rd }}$ sumarginal spines are placed close together. Marginal teeth are concolourous with remainder of cuticle. Vasiform orifice is cordate and operculum almost filling the orifice (DuBEY \& Ko, 2012). 


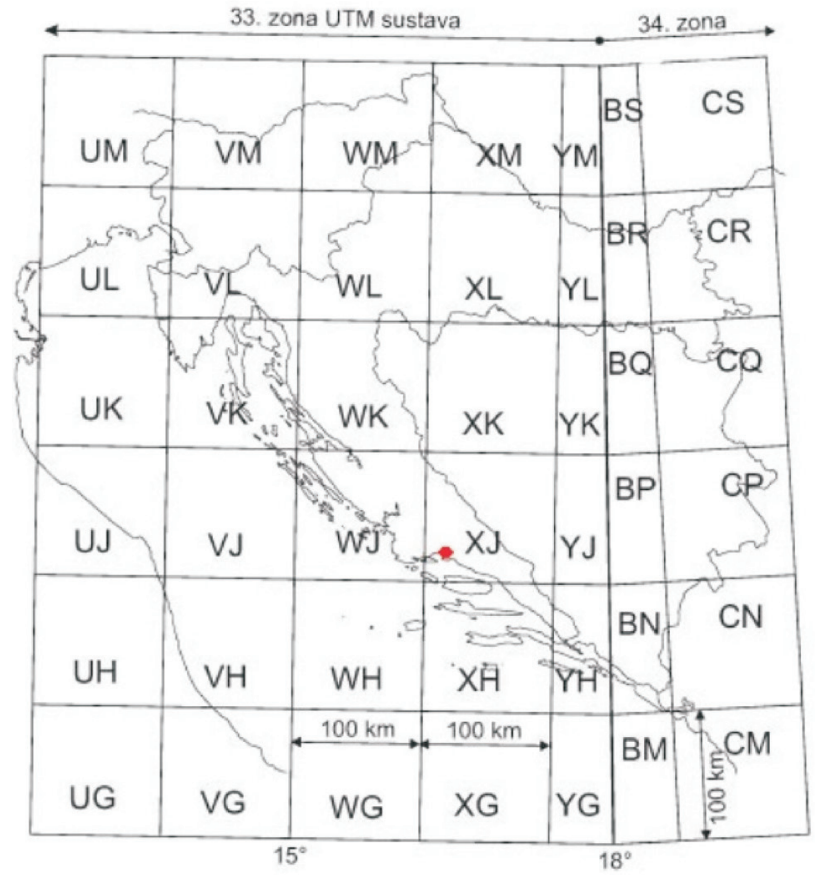

Fig. 15. Finding place of Aleurocanthus spiniferus (Quaintance 1903) in Croatia

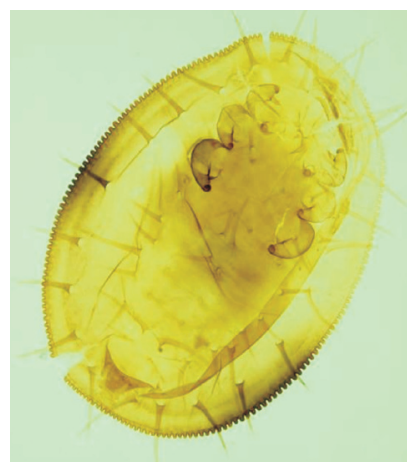

Fig. 16. Permanent microscopic slide of a pupal case of Aleurocanthus spiniferus (Quaintance 1903) (Photo: M. Šimala)

\section{Aleuroclava aucubae (Kuwana 1911)}

The whitefly genus Aleuroclava Singh 1931 is known to occur almost worldwide and is represented by 108 described species. A. aucubae is an East palearctic species previously recorded in Japan, Taiwan and China and later introduced into the USA (Evans, G. A., 2006). In Europe, it was reported for the first time in Italy in 2006 (Pellizzari \& ŠmalA, 2007) but that publication wrongly identified this species as A. guyavae (Takahashi 1932) (Mifsud et al., 2010). A. aucubae was first found in Croatia in 2013 on lemon seedlings from domestic production in two nurseries in Istria. Puparia occur on the leaves of host plants in low numbers, only 1 to 2 per leaf. It is also significant that they do not secret honey dew abundantly. However, we have recorded a very high A. aucubae population of 50 puparia per leaf on the leaves of a fig tree in a park in Opatija. It is obvious that the fig tree is a very suitable host for this species (Šimala et al., 2013; ŚmALA et al., 2014). It is a polyphagous species and according to Mound \& Halsey (1978), A. aucubae has been recorded from 15 plant families. This whitefly species overwinters in the puparial stage (SELJAK, 2012).

Collection data: Poreč (UL 9009) 4 July 2013, Rovinj (UK 9393) 4 July 2013 on C. limon; Zagreb (WL 7772) 23 August 2013 on C. x limon; Opatija (VL 4520) 22 August 2013 on Ficus carica L., Pittosporum tobira (Thunb,) W. T. Aiton, Photinia sp. and C. x aurantium (Fig. 17).

Puparia of A. aucubae are very small $0.72 \mathrm{~mm}-0.84 \mathrm{~mm}$ in length, elliptical, dark black with a characteristically ornamented surface (SELJAK, 2012) (Fig. 18). Abdomen has a very sclerotized median rhachis without lateral arms. Thoracic tracheal clefts are distinct with its fold represented by an oval or semi-circular shaped area extending into the 


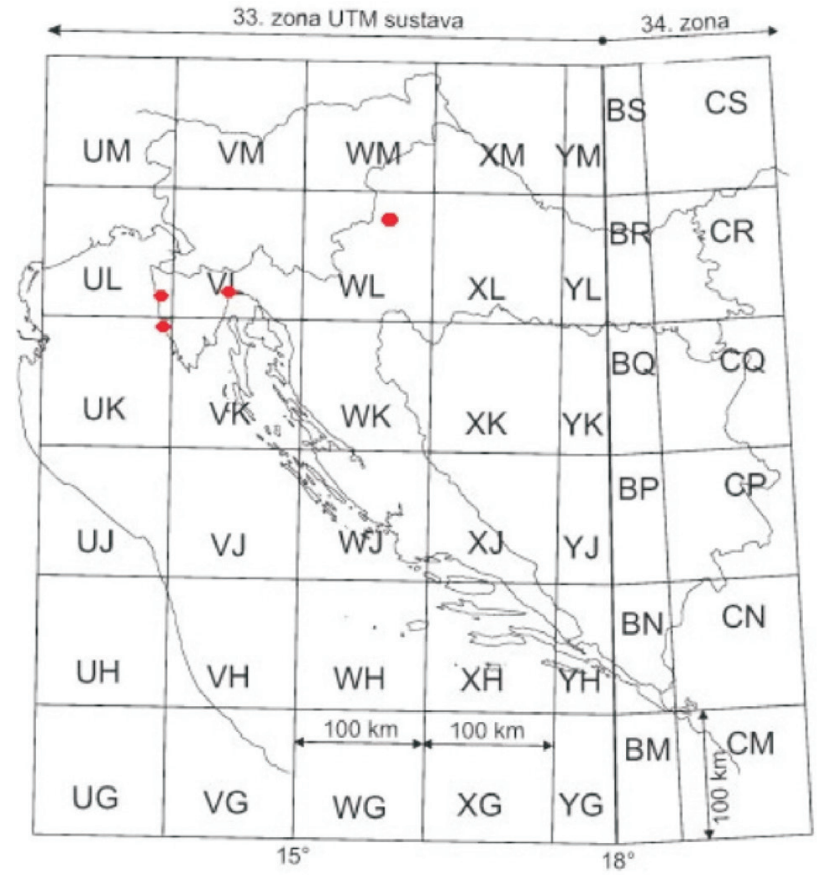

Fig. 17. Distribution of Aleuroclava aucubae (Kuwana 1911) in Croatia determined by the authors

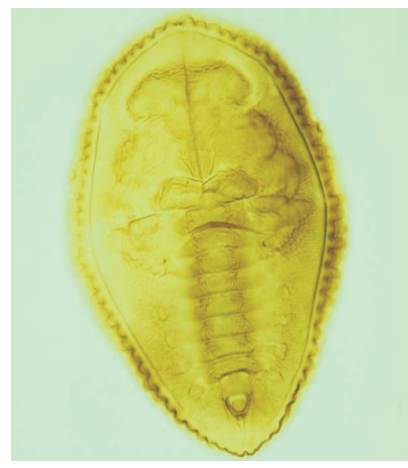

Fig. 18. Permanent microscopic slide of a puparium of Aleuroclava aucubae (Kuwana 1911) (Photo: M. Šimala)

submarginal area (SuH, 2010; SuH \& Evans, 2012). Dorsal disk of pupal case has many furrow-like pale linear markings and many irregular pale lines on the cephalothorax and lateral on the median segmented area of the abdomen. These lines form a kind of apparent reticulation. Margin of pupal case is widely crenate, without distinct teeth. A rounded, low tubercle with many wavy markings is present laterally on abdominal tergites $4-7$. Median tubercle of each abdominal segment is more developed, larger, reaching the anterior margin of segment. Caudal tracheal cleft is very small, narrow and longer than wide. Vasiform orifice is deeply notched posteriorly; the notch is longer than wide, narrowed caudally. Caudal furrow is slender, very narrow, a little widened near the hind end, without markings, lateral margins a little heavier sclerotized (TAKAHAsHI, 1952).

Received October 16, 2014

\section{REFERENCES}

Bink-Moenen, R. M., 1983: Revision of the African whiteflies (Aleyrodidae). Monografieën van de Nederlandse Entomologische Vereniging 10, $211 \mathrm{pp}$.

Bink-Moenen, R. M. \& Gerling, D., 1990: Aleyrodidae of Israel. Boll. Lab. Ent. agr. Filippo Silvestri, 47, 3-49.

Bink-Moenen, R. M., 1992: Whitefly from mediterranean oaks (Homoptera: Aleurodidae). Systematic Entomology 17, 21-40.

Dobreanu, E. \& Manolache, C., 1969: Homoptera Aleyrodoidea subfamilia Aleyrodinae. Fauna Republicii Socialiste România. Insecta 8 (5), 1-152.

DoмAc, R., 1967: Ekskurzijska mala flora Hrvatske i susjednih područja. Medicinska naklada, Zagreb. 543 pp. 
Domac, R., 1994: Flora Hrvatske, priručnik za određivanje bilja. Školska knjiga Zagreb. 504 pp.

Dubey, A. K. \& Ko, C. C., 2009: A review of the genus Aleurolobus Quaintance \& Baker (Hemiptera: Aleyrodidae) from Taiwan, based mainly on pupal morphology with a description of a new species. Entomological Science 12, 51-66.

Dubey, A. K. \& Ko, C. C., 2012: Sexual dimorphism among species of Aleurocanthus Quaintance \& Baker (Hemiptera: Aleyrodidae) in Taiwan, with one new species and an identification key. Zootaxa 3177, $1-23$.

Eppo/CABI, 1997: Aleurocanthus spiniferus. In Quarantine Pests for Europe, $2^{\text {nd }}$ edn. CAB International, Wallingford, 21-24.

Evans, G. A., 2006: The Whiteflies (Hemiptera: Aleyrodidae) of the World and Their Host Plants and Natural Enemies. URL:http://www.sel.barc.usda.gov:591/1WF/World-Whitefly-Catalog.pdf. (15.1.2014.).

Hodges, G. S. \& Evans, G. A., 2005: An Identification Guide to the Whiteflies (Hemiptera: Aleyrodidae) of the Southeastern United States. Florida Entomologist 88 (4), 518-534.

Horvat, S., ŽeleZnjak, Ž. \& LAPAine, M., 2003: Vojni topografsko-kartografski sustav Republike Hrvatske. Kartografija i geoinformacije 2 (2), 75-85.

Huldén, L., 1986: The whiteflies (Homoptera, Aleyrododea) and their parasites in Finland. Notulae Entomologicae 66, 1-40.

Iaccarino, F. M., 1981: Aleirodidi nuovi o pocco noti per l'Italia. Boll. Lab. Ent. Agr. "F. Silvestri" 38, $143-156$.

IACCARINO, F. M. \& VigGiAnI, G., 1984: Gli stadi preimmaginali degli Aleyrodidae: 2. Aleurotuba jelineki (Frauenf.) e Aleuroviggianus adrianae Iacc. Boll. Lab. Ent. Agr. "F. Silvestr" 41, 137-146.

Jansen, M. G. M., 2001: Diagnostic activities Plant Protection Service Wageningen, The Netherlands. Ministry of Agriculture, Nature Management and Fisheries, 42-44.

Jesudasan, R. W A. \& David, B. V., 1990: Revision of two whitefly genera, Aleuroclava Singh and Aleurotuberculatus Takahashi (Homoptera: Aleyrodidae). Entomological Series 2, 1-13.

Martin, J. H., 1987: An identification guide to common whitefly pest species of the world (Homoptera, Aleyrodidae). Tropical Pest Management 33 (4), 298-322.

Martin, J. H., 1996: Neotropical whiteflies of the subfamily Aleurodicinae established in the western Palaearctic (Homoptera: Aleyrodidae). Journal of Natural History 30, 1849-1859.

Martin, J. H., 1999: The whitefly fauna of Australia (Sternorrhyncha: Aleyrodidae). A taxonomic account and identification guide. Technical Paper 38, CSIRO Australia. 197 pp. Martin, J. H., Mifsud, D. \& RAPISARDA, C., 2000: The whiteflies (Hemiptera: Aleyrodidae) of Europe and the Mediterranean Basin. Bulletin of Entomological Research 90. 407-448.

Martin, J. H., 2005: Whiteflies of Belize (Hemiptera: Aleyrodidae) Part 2 - a review of the subfamily Aleyrodinae Westwood. Zootaxa 1098, 1-116.

Martin, J. H. \& Mound, L. A., 2007: An annotated check list of the world's whiteflies (Insecta: Hemiptera: Aleyrodidae). Zootaxa 1492, 1-84.

Mifsud, D., Cocquempot, C., Mühlethaler, R., Wilson, M. \& Streito, J. C., 2010: Other Hemiptera Sternorrhyncha (Aleyrodidae), Phylloxeroidea, and Psylloidea) and Hemiptera Auchenorrhyncha Chapter 9.4, BioRisk 4 (1), 511-552.

Mound, L. A., 1966: A revision of the British Aleyrodidae (Hemiptera: Homoptera). Bulletin of British Museum (Natural History) Entomology 17 (9), 399-428.

Mound, L. A. \& Halsey, S. H., 1978: Whitefly of the world. A systematic catalogue of the Aleyrodidae (Homoptera) with host plant and natural enemy data. British Museum (Natural History) and John Wiley and Sons, Chichester. 340 pp.

NovaK, P., 1940: Gli insetti dannosi in Dalmazia. Bollettino della Soc. Adriatica di Scienze naturali. Trieste. $38,5-38$.

Oерт/Eтpo, 2002: Diagnostic protocols for regulated pests. Aleurocanthus spiniferus. Bulletin OEPP/ EPPO Bulletin 32, 255-259.

Pellizzari, G. \& Šimala, M, 2007: First record of Aleuroclava guyavae (Takahashi, 1932) (Hemiptera, Aleyrodidae) in Europe. Bollettino di Zoologia agraria e di Bachicoltura, Ser. II, 39 (2), 91-95.

PorcelLI, F., 2008: First record of Aleurocanthus spiniferus (Homoptera: Aleyrodidae) in Apulia, Southern Italy. Bulletin OEPP/EPPO Bulletin 38, 518-520. 
Radonjić, S. \& Hrnčić, S., 2013: Aleurocanthus spiniferus Quaintance (Hemiptera: Aleyrodidae), nova vrsta na citrusima u Crnoj Gori. Zbornik rezimea radova, XII Savetovanje o zaštiti bilja, Zlatibor, 25-29. novembar 2013. godine, 128.

Rapisarda, C., 1982: Appunti morfologici su alcuni aleirodi (Homoptera, Aleyrodidae) della fauna siciliana. Boll. Lab. Ent. Agr. "F. Silvestri" 39, 71-95.

SElJAK, G., 2012: Six new alien phytophagous insect species recorded in Slovenia in 2011. Acta Entomologica Slovenica 20 (1), 31-44.

SuH, S. J., 2010: New Records of Aleuroclava (Hemiptera: Aleyrodidae) from Korea. Kor. J. Appl. Entomol. 49 (1), 1-4.

Suh, S. J. \& Evans, G. A., 2012: Additions to the Whitefly Fauna of Korea with a Key to Species (Hemiptera: Aleyrodidae). Kor. J. Appl. Entomol. 51 (2), 163-170.

ŠIlić, Č., 1988: Atlas drveća i grmlja. "Svjetlost", Sarajevo. 218 pp.

ŠILIĆ, Č., 1988a: Šumske zeljaste biljke. "Svjetlost”, Sarajevo. 272 pp.

ŠILIĆ, Č., 1988b: Endemične biljke. "Svjetlost", Sarajevo. 227 pp.

ŠILIĆ, Č., 1990: Ukrasno drveće i grmlje. "Svjetlost”, Sarajevo. 221 pp.

Šimala, M. \& Masten Milek, T., 2008: A check-list of whiteflies (Insecta: Hemiptera: Aleyrodidae) of Croatia. Nat. Croat. 17 (3), 169-181.

Šimala, M., Masten Milek, T. \& Korić, B., 2009: Whitefly species (Hemiptera: Aleyrodidae) recorded on imported ornamental plants in Croatia from 2005-2008. Zbornik predavanj in referatov 9. slovenskega posvetovanja o varstvu rastlin Nova Gorica, 4.-5. marec 2009, 389-396.

Šimala, M. \& Masten Milek, T., 2013: Prvi nalaz karantenske vrste štitastog moljca Aleurocanthus spiniferus Quaintance, 1903 (Hemiptera: Aleyrodidae) u Hrvatskoj. Glasilo biljne zaštite 13 (6), 425433.

Šimala, M. \& Masten MiLeK, T., 2013a: First record of the orange spiny whitefly, Aleurocanthus spiniferus Quaintance, 1903 (Hemiptera: Aleyrodidae) in Croatia. Abstract volume of $11^{\text {th }}$ Slovenian Conference on Plant Protection with international participation (And the round table of risks reduction in phyto-pharmaceutical products use in the frame of CroSustaln project), Bled, Slovenia, 5.-6.3. 2013, 354-358.

Šimala, M., Masten Milek, T. \& Pintar, M., 2013: Novointroducirane invazivne vrste štitastih moljaca (Hemiptera: Aleyrodidae) Aleurocanthus spiniferus Quaintance, 1903 i Aleuroclava aucubae Kuwana, 1911 potencijalni fitosanitarni rizik za uzgoj agruma u Republici Hrvatskoj. Zbornik rezimea X Simpozijuma o zaštiti bilja, Sarajevo, 5.-7.11.2013., 88-89.

Šimala, M., Masten Milek, T. \& Pintar, M. 2014: Aleuroclava aucubae (Kuwana, 1911) [Hemiptera: Aleyrodoidea: Aleyrodidae] nova vrsta štitastog moljca u Republici Hrvatskoj. Glasilo biljne zaštite 14 (4), 287-291.

TAKahashi, R., 1938: Notes on the Aleyrodidae of Japan (Homoptera) VI. Kontyù 12, 70-74.

TAKAhashi, R., 1952: Aleurotuberculatus and Parabemisia of Japan (Aleyrodidae, Homoptera) Miscellaneous Reports of the Research Institute for Natural Resources, Tokyo, 25, 17-24.

Watson, G. W. \& Chandler, L. R., 1999: Identification of Mealybugs important in the Caribbean Region with notes on preparation of whitefly pupae for identification. Commonwealth Science Council and CAB International. 40 pp.

ZAHRADNIK, J., 1985: La revision des Aleurodes de pays tcheques (Sternorrhyncha: Aleyrodinea) I. Vestnik Československe Zoologičke Společnosti v Praze, 49, 301-320.

Zahradnik, J., 1991: Taxonomisches und Faunistisches über europäische Mottenläuse (Aleyrodinea). Acta Universitatis Carolinae Biologica 35, 111-118.

ŽANIĆ, K., 2006: Mediterranean Croatia current whitefly observations. URL:http://www.whitefly.org./ Newsletter/WhiteflyNews0906/WhiteflyNews0906.asp (17.12.2006.). 